\title{
MEMÓRIAS DE EDUCADORAS FEIRENSE: PROCESSO FORMATIVO PARA A DOCÊNCIA NO CURSO DE MAGISTÉRIO DO SEGUNDO GRAU 1962-1971
}

\author{
GABRIEL DALTRO \\ 1. Gabriel Cabral Daltro, Licenciatura em Educação Física, Universidade Estadual de Feira de Santana, e-mail: \\ ggccdd2008@hotmail.com \\ 2. Irlana Jane Menos da Silva, Departamento de Educação, Universidade Estadual de Feira de Santana, e-mail: \\ irlanamenas $a$ hotmail.com
}

PALAVRAS-CHAVE: Educadoras; Século XX; Docência.

\section{INTRODUÇÃO}

Este plano de trabalho intitulado Memórias de Educadoras Feirenses: Processos Formativos para Docência no Curso de Magistério do Segundo Grau 1962-1971 está vinculado ao projeto de pesquisa Educadoras Baianas: Saberes e Experiências de Práticas Pedagógicas de Professoras da Educação Básica no Século XX. Por volta do século XIX, foi possivel identificar um desinteresse por grande parte dos indivíduos do sexo masculino pela educação. Isto foi decorrente de fatores de ordem econômica $\mathrm{e}$ social, devido à diminuição do valor recebido pelos educadores destinado ao pagamento do aluguel do espaço escolar, redução dos seus salários, fiscalização mais efetiva do trabalho docente, limitando assim a mobilidade do profissional desta área, exigindo que o professor ficasse fixado no local de ensino (SILVA 2008). Com o desinteresse por parte dos educadores masculinos em relação à docência, passamos a ver a partir dos discursos de autoridades locais e intelectuais daquela época, o fortalecimento de quem afirmava que a educação é uma atividade feminina, utilizando como argumentação uma mistura de elementos sobre a natureza humana, tendência e vocação.

MATERIAL E MÉTODOS OU METODOLOGIA (ou equivalente)

Para providenciar alguns itens deste esboço metodológico da pesquisa foi constituída por divulgação no Jornal Folha do Norte, na base de dados do Museu Casa do Sertão e o acervo de Docentes formadas na antiga Escola Normal de Feira de Santana atua Instituto Gastão Guimarães, onde foram pesquisados através dos seguintes descritores: Escola Normal, Professora formada no período entre 1962 á 1971.

\section{RESULTADOS E/OU DISCUSSÃO (ou Análise e discussão dos resultados)}

Foi feito um levantamento no acervo do Instituto de Educação Gastão Guimarães na buscar de professoras que se formaram na antiga Escola Normal de Feira de Santana no período de 1962-1971 a fim de saber quem foram as professoras que se formaram e como foi o seu histórico. Também foram feitas pesquisas no Jornal Folha do Norte a fim de saber quais foram as professoras homenageadas nesse período proposto pelo trabalho tendo como exemplo encontrado em exemplares a professora Edna Laureana de Oliveira homenageada pelo CCREMAN (Centro Cultural Recreativo Monsenhor Amílcar Marques) dando a sua biblioteca o nome da renomada educadora em 23 de julho de 1966 e a Professora Maria Angélica Martins que recebeu em solenidade o diploma de professora por ter se destacado em sua formação como aluna caprichosa em 11 de janeiro de 1964. 


\section{CONSIDERAÇÕES FINAIS (ou Conclusão)}

A partir do que foi trabalhado no decorrer da pesquisa conclui-se que o século XIX foi de grande importância para a educação, pois a luta das educadoras teve inicio a partir do século XIX e com isso os resultados foram aparecendo e só foi aumentando cada vez mais do século $\mathrm{XX}$ em diante. Com o desinteresse do sexo masculino gerado pela desvalorização da profissão e a baixa remuneração no que diz respeito ao trabalho docente que até então era exercido apenas por ele, as mulheres conseguiram ganhar espaço na docência e como consequência disso as meninas puderam ter acesso ao ensino.

\section{REFERENCIAS}

Acervo de Docentes Formadas na antiga Escola Normal de Feira de Santana atual Instituto de Ensino Gastão Guimarães.

Jornal Folha do Norte na base de dados do Museu Casa do Sertão 